\title{
Original Intent and Popular Government: A Madisonian Perspective
}

\begin{abstract}
In 1791 two former political allies reached opposite conclusions on the constitutionality of chartering a national bank to serve the Federal government of the United States. Alexander Hamilton, who was then Secretary of the Treasury, argued that the U.S. Constitution conferred limited, but essentially bottomless, powers to Congress in pursuit of the public good. James Madison, at that time an elected member of the U.S. House of Representatives, argued that powers conferred on Congress were limited in number, and reach, by conventions that ratified the Constitution in 1787-1788. Hamilton won the battle on the bank, but lost the war, as Madison's strict construction of the Constitution in terms of the understanding of those who ratify, and amend, it prevailed in the long run. The broad construction favored by Hamilton has rarely carried the day in American jurisprudence.
\end{abstract}

Keywords: popular sovereignty, compact theory of ratification, broad construction, strict construction, interposition, nullification

In the U.S.A. controversial issues, e.g. gun control, abortion, affirmative action and environmental regulation spring from discussions about problems and potential solutions, but end in questions about whether governmental action is permitted on the issue, and if so, which level of government has authority to make policy, and which branch within that level of government ought to control the outcome. Ultimately, procedural issues like these must be resolved by the American judiciary, and many issues are framed with that in mind.

The judiciary determines what the Constitution permits, or bars. But there are as many readings of the Constitution as there are readers, and as a matter of practical necessity the courts must decide which reading prevails. An important school of thought holds that judges ought to interpret the Constitution with the intent of the Framers in mind. As the authors of the Constitution, the Framers' interpretation is considered definitive; it served Americans well for more than 200 years, except on those occasions when we foolishly strayed from the 
path of our forebearers. By returning to that path and heeding the wisdom of the founders, we can preserve the republic for the ages, or so the reasoning goes.

This is a conservative argument. Or rather it is a conservative family of arguments, for any understanding of the Framers' intent depends on who is counted among the Framers. The Federalists certainly belong in this company, but what about the Antifederalists? They opposed the Constitution proposed by the Philadelphia convention, but insisted on a Bill of Rights, and for that contribution ought to be counted among the founders, according to Storing (1981). The fact that most citizens value their rights more highly than the complex machinery of checks and balances designed by Federalists suggests that Storing might be right.

Nevertheless, the company of Framers is generally restricted to the Federalists, and then further reduced to such leading Federalists as Alexander Hamilton and James Madison. As the principal authors of the Federalist Papers their intent matters most, or at least that is the silent understanding of many adherents to this doctrine of constitutional interpretation. I take this presumption as the starting point for this essay, which asks how Hamilton and Madison intended us to interpret the Constitution.

Did these Framers expect us to defer to their interpretation of the Constitution? To answer this question, I review the 1791 debate over the constitutionality of a national bank. In this debate Hamilton, who was then Secretary of the Treasury, advanced the doctrine of implied powers in order to explain why Congress had the authority to incorporate a bank owned and directed by private investors. Madison, a member of the House of Representatives from Virginia took the opposite view. He believed the bank legislation was unconstitutional and developed a doctrine of strict construction to make the case. Out of this clash emerged two "founding" theories of interpretation that define the major alternatives in American constitutional history. Even today, the distinction between broad and strict construction is used to characterize differences in Constitutional orientation.

Hamilton and Madison held different views on Constitutional interpretation, but interestingly neither of them valued the Framers' intent, as expressed in the proceedings at Philadelphia and articulated in the Federalist Papers. Instead, each man derived a theory of constitutional interpretation from fundamental political principles and used his theory to explicate specific passages in the Constitution and reconcile them to each other. In recommending these theories Hamilton and Madison, far from intending that others ought to consult the Framers' intention when reading the Constitution, expected people to reason their way through contending arguments. Principles of interpretation mattered to them, not the leading actors in a previous political drama. The Federalist $\mathrm{Pa}$ pers, therefore, cannot resolve the Framer's intent.

Madison's rationale for strict construction is important for another reason as well. Based on his criticism of majority factions in Federalist 10 and his reliance on long terms, indirect elections and executive appointments, critics are wont to 
accuse Madison of being undemocratic. The charge has merit, since he clearly wanted to insulate the day-to-day operations of government from the passions of popular politics. However, it is difficult to sustain the simple charge that Madison was undemocratic once his commitment to popular sovereignty in Constitutional matters comes into view.

Madison insisted on referring questions of Constitutional interpretation to the understanding of those who are "parties to the instrument," i.e. state conventions that ratified the Constitution in 1787-1788. The product of these deliberations was a framework of government that reflected the will of the people, or an extraordinary majority of them at any rate. Madison's deference to the people on "great issues" suggests that the charges against him must be reduced, or perhaps that more serious charges ought to be brought against Hamilton, who paid scant regard to ratifying conventions. Either way, this poses a challenge to arguments that Americans ought to defer to the Framers.

I conclude my essay with observations on a related issue, Madison's turn toward public opinion in the 1790s. During this time Madison became convinced that Hamilton and the Federalists were usurping power, and that it was necessary to counter them by mobilizing "parties to the instrument" against them. This reassessment of the "mischief of faction" brought Madison's political theory into closer alignment with his commitment to popular sovereignty in constitutional matters, or so I conclude.

\section{Hamilton's Doctrine of Implied Powers}

As a delegate to the Philadelphia convention, probable author of 51 Federalist Papers, and the nation's first Secretary of the Treasury, Alexander Hamilton was undeniably a Founding Father. His interpretation of the Constitution is essential reading for those who would resolve constitutional questions with reference to "the Framers' intentions." Put simply, Hamilton argued that the people of the United States assigned important, but limited, responsibilities to the Federal government. To fulfill these responsibilities the Federal government was assigned powers that ought to be understood broadly, or to use his word, liberally. Any limitations on those powers (apart from their intended use) might deprive the government of means necessary for carrying out the will of the people, which under dangerous conditions might lead to a general loss of liberty and its blessings. That is not what the people intended, so the powers of government should be construed broadly, as circumstances dictate.

Hamilton expressed this view forcefully in his contributions to the Federalist Papers, wherein he noted the primary responsibilities of the Federal government: "the common defense of the members - the preservation of the public peace as well against internal convulsions as external attacks - the regulation of 
commerce with other nations and between States - the superintendence of our intercourse, political and commercial, with foreign countries." (Hamilton, Federalist 23,2003 , pp. 106-110, at p. 106). To fulfill these responsibilities, and only to fulfill these responsibilities, powers were expressly conferred upon the various branches of the Federal government. Additional powers were implied, and for Congress the implication was expressly conceded in the "necessary and proper" clause of Article I, Section 8. The combination of express and implied powers ran very deep, though their range of application was confined to the "principal purposes to be answered by Union." (Hamilton, Federalist 23, 2003, pp. 106-110, at pp. 106-107). ${ }^{1}$

Thus, Hamilton insisted:

The authorities essential to the care of the common defense are these - to raise armies to build and equip fleets - to prescribe rules for the government of both - to direct their operations - to provide for their support. These powers ought to exist without limitation: Because it is impossible to foresee or define the extent and variety of national exigencies, or the correspondent extent \& variety of the means which may be necessary to satisfy them. The circumstances that endanger the safety of nations are infinite; and for this reason no constitutional shackles can wisely be imposed on the power to which the care of it is committed. This power ought to be coextensive with all the possible combinations of such circumstances; and ought to be under the direction of the same councils, which are appointed to preside over the common defense. (Federalist 23, 2003, pp. 106-110, at pp. 106-107)

The power of the purse underwrites this broader power of the sword, Hamilton wrote in Federalist 30:

It has been already observed, that the Foederal government ought to possess the power of providing for the support of the national forces; in which proposition was intended to be included the expense of raising troops, of building and equipping fleets, and all other expenses in any wise connected with military arrangements and operations. But these are not the only objects to which the jurisdiction of the Union, in respect to revenue, must necessarily be empowered to extend - It must embrace a provision for the support of the national civil list - for the payment of the national debts contracted, or that may be contracted - and, in general, for all those matters which will call for disbursements out of the national treasury. (Federalist 30, 2003, pp. 137-141, at p. 137).

His conclusion was that there must be a general power of taxation in one shape or another, and a depository for that that purpose.

Hamilton's liberal interpretation of Congress's power of the purse became apparent in 1791, when he proposed the incorporation of a national bank. The Bank of the United States would be a depository for government funds and was a key element of the Treasury Secretary's plan to generate capital for investments

Italics and words in capitals are in the original, but underlined text is my emphasis. 
to underwrite the development of a commercial republic. The bank would also loan money to the government in emergencies, regularize banking practices across the nation, and implement a uniform currency. All of this made good economic sense, but the bank's constitutionality was challenged by Attorney General Edmund Randolph, Secretary of State Thomas Jefferson, and Representative James Madison. Their fellow Virginian George Washington harbored doubts, too, and Hamilton had to persuade him of the bank's constitutionality before the President would sign the enabling legislation.

Hamilton carried the day with his "Opinion on the Constitutionality of An Act to Establish a Bank," presented to Washington on February 23, 1791 (Papers of Alexander Hamilton, 1972, pp. 97-134). The Constitution did not expressly confer upon Congress the power to charter a national bank, Hamilton admitted. However, it did grant powers "necessary and proper" for the execution of powers expressly granted to the legislature. These included the power to tax, the authority to borrow, issue a standard currency, and regulate commerce between states and with other countries. A national bank, Hamilton argued, was "necessary and proper" for exercising these powers and carrying out the responsibilities of the Federal government.

The former artillery captain first appealed to common sense:

necessary often means no more than needful, requisite, incidental, useful, or conductive to. It is a common mode of expression to say, that it is necessary for a government or a person to do this or that thing, when nothing more is intended or understood, than that the interests of the government or person require, or will be promoted, by the doing of this or that thing. The imagination can be at no loss for exemplifications of the use of the word in this sense. (Papers of Alexander Hamilton, 1972, vol. 8 , p. 102)

Bigger guns were then brought to bear, as Hamilton contended

it was the intent of the [Philadelphia] convention, by that clause to give a liberal latitude to the exercise of the specified powers. The expressions have peculiar comprehensiveness. They are - 'to make all laws, necessary \& proper for carrying into execution the foregoing powers \& all other powers vested by the constitution in the government of the United States, or in any department or officer thereof.' To understand the word as the Secretary of State does, would be to depart from its obvious and popular sense, and to give it a restrictive operation; an idea never before entertained. It would be to give it the same force as if the word absolutely or indispensably had been prefixed to it. (Papers of Alexander Hamilton, 1972, p. 103)

Unfortunately for Hamilton, the idea of interpreting "necessary" in a broad sense had been entertained in Philadelphia. Delegates to the convention explicitly rejected a proposal to grant Congress the power to charter corporations for navigational improvements, as Jefferson and Madison loudly protested when the bank charter was proposed. Hamilton nimbly responded that 
very different accounts are given of the import of the proposition and of the motives for rejecting it. Some affirm that it was confined to the opening of canals and obstructions in rivers; others, that it embraced banks; and others, that it extended to the power of incorporating generally. Some again alledge, that it was disagreed to, because it was thought improper to vest in Congress a power of erecting corporations - others, because it was thought unnecessary to specify the power, and inexpedient to furnish an additional topic of objection to the Constitution. In this state of the matter, no inference whatever can be drawn from it. (Papers of Alexander Hamilton, 1972, vol. 8, p. 111)

But Hamilton did not rest his defense of the bank solely on claims about the debate on charters in the Philadelphia convention.

The Secretary of State will not deny, that whatever may have been the intention of the framers of a constitution, or of a law, that intention is to be sought for in the instrument itself, according to the usual \& established rules of construction. Nothing is more common than for laws to express and effect, more or less than was intended. If then a power to erect a corporation, in any case, be deducible by fair inference from the whole or any part of the numerous provisions of the constitution of the United States, arguments drawn from extrinsic circumstances, regarding the intention of the convention, must be rejected. (Papers of Alexander Hamilton, 1972, vol. 8 , p. 111)

Thus, Hamilton ultimately denied the relevance of Framers' intentions in deciding constitutional questions. The true touchstone was

this sound maxim of construction namely, that the powers contained in a constitution of government, especially those which concern the general administration of the affairs of a country, its finances, trade, defence \&c ought to be construed liberally for advancement of the public good. This rule does not depend on the particular form of a government or on the particular demarkation of the boundaries of its powers, but on the nature and objects of government itself. The means by which national exigencies are to be provided for, national inconveniences obviated, national prosperity promoted, are of such infinite variety, extent and complexity, that there must, of necessity, be great latitude of discretion in the selection \& application of those means. (Papers of Alexander Hamilton, 1972, vol. 8, p. 105)

\section{Madison's Doctrine of Strict Construction}

Hamilton won the battle over the bank in 1791, but Madison's interpretation of the Constitution proved more convincing over the long run. He expounded the doctrine of strict construction in speeches before the House of Representatives on February 2 and 8, 1791. The speeches were in opposition to the bank bill and raised both prudential and constitutional objections to Hamilton's proposal. The 
constitutional objections stemmed from Madison's conviction that Congress had no authority to charter corporations of any sort, let alone a national bank controlled by private directors.

Madison denied that arguments in favor of a bank could be derived from the Constitution's preamble. "The preamble," said Madison, "only states the objects of the confederation, and the subsequent clauses designate the express powers by which those objects are to obtained," and provide a means of amending the list of designated powers "more fully to effect the purposes of the confederation." (Madison, Speech on the Bank Bill, Papers of James Madison, 1991, vol. 13, pp. 372-388, at p. 384). To understand the preamble as a separate authorization of power, Madison averred, "would give to Congress an unlimited power; would render nugatory the enumeration of particular powers; would supercede all the powers reserved to state governments." (Madison, Speech on the Bank Bill, $\mathrm{Pa}$ pers of James Madison, 1991, vol. 13, pp. 372-388, at p. 374).

Madison also rejected the contention that Congress's power to borrow implied the authority to establish a bank, as proponents of the bank claimed. The bank bill, Madison noted, "does not borrow a shilling," and as such the bank was not authorized under the borrowing power except under a dangerously "forced construction." The dire implications of this forced construction were clear to Madison:

Mark the reasoning on which the validity of the bill depends. To borrow money is made the end and the accumulation of capitals, implied as the means. The accumulation of capitals is then the end, and a bank implied as the means. The bank is then the end, and a charter of incorporation, a monopoly, capital punishments, \&c. implied as the means. (...) If implications, thus remote and thus multiplied, can be linked together, a chain may be formed that will reach every object of legislation, every object within the whole compass of political economy. (Madison, Speech on the Bank Bill, Papers of James Madison, 1991, vol. 13, at pp. 372-388, at p. 376)

Finally, Madison denied Federalist claims that a bank was "necessary and proper" to execute laws Congress was undeniably authorized to make. Madison commenced the attack on this crucial claim by insisting that "Whatever meaning this clause may have, none can be admitted, that would give an unlimited discretion to Congress," for that would defeat the purpose of checks and balances, which were the bulwark against tyranny. Surely, Madison, argued, any such "interpretation that destroys the very characteristic of the government cannot be just." (Madison, Speech on the Bank Bill, Papers of James Madison, 1991, vol. 13, at pp. 372-388, at pp. 374, 376).

Having posited the seemingly incontrovertible proposition that "necessary and proper" powers were limited, Madison laid down rules for locating these limits. The meaning of this clause "must, according to the natural and obvious force of the terms and the context, be limited to means necessary to the end, and 
incident to the nature of the specified powers." The key language here is the conjunction of necessity and incidence to the nature of specified powers. Where there was disagreement over the "force" of these terms as they applied to specific issues, "the meaning of the parties to the instrument...is a proper guide," according to Madison (Speech on the Bank Bill, Papers of James Madison, 1991, vol. 13, at pp. 372-388, at p. 376).

To ascertain "the meaning of the parties to the instrument" it was necessary to consider discussions that led to the approval of the instrument, for "Contemporary and concurrent expositions are a reasonable evidence of the meaning of the parties." Thus, Madison recommended something like the doctrine of Framers' intent as we understand it today, but with this crucial difference: the relevant Framers are those who approved the instrument, not those who proposed it. (Madison, Speech on the Bank Bill, Papers of James Madison, 1991, vol. 13, pp. 372-388, at p. 374).

This becomes evident in Madison's review of "contemporary expositions" given to the constitution in 1787-1788. He "well recollected that a power to grant charters of incorporation had been proposed in the general convention and rejected," and for this reason believed that Congress had no authority to establish a national bank (Madison, Speech on the Bank Bill, Papers of James Madison, 1991, vol. 13, pp. 372-388, at p. 374). But Madison passed quickly over the Framers' intentions, turning to debates over the extent of Congressional power in state ratifying conventions. These he considered at length, and quite systematically, in order to ascertain how "parties to the instrument" understood the Constitution they ratified.

The scope of powers allocated to the Federal government was the leading concern of Antifederalists, and a central issue in the ratifying conventions. The absence of a bill of rights aggravated the problem and became a rallying point for opponents of the Constitution in Virginia, New York, and some other states. Federalists were obliged to answer those who characterized the absence of a bill of rights as a fatal omission. Writing as Publius, Hamilton ventured the idea that bills of rights, though useful in limiting the prerogatives of monarchs, "have no application to constitutions professedly founded upon the power of the people, and executed by their immediate representatives and servants. Here, in strictness, the people surrender nothing, and as they retain every thing, they have no need of particular reservations." (Hamilton, Federalist 84, 2003, p. 419).

This argument, Madison observed in 1791, clearly presupposed "that the powers not given were retained; and that those given were not to be extended by remote implications. On any other supposition, the power of Congress to abridge the freedom of the press, or the rights of conscience, \&c. could not have been disproved." And if the Federalists had not been able to "disprove" the power of Congress to limit or infringe upon fundamental liberties, the Constitution might not have been ratified in key states such as Virginia and New York, or so 
he intimated (Madison, Speech on the Bank Bill, Papers of James Madison, 1991, vol. 13, pp. 372-388, at p. 380).

Madison dwelled on this point. "The explanations in the state conventions all turned on the same fundamental principle, and on the principle that the terms necessary and proper gave no additional powers to those enumerated." Speaking on the floor of the House of Representatives, he read from the debates of the Pennsylvania, Virginia and North Carolina conventions, showing how the Constitution was vindicated by its supporters against charges of a dangerous latitude in its assignment powers. Madison "thought it probable that the sentiments delivered might in many instances have been mistaken, or imperfectly noted; but the complexion of the whole, with what he himself and many others must recollect, fully justified the use he had made of them." (Madison, Speech on the Bank Bill, Papers of James Madison, 1991, vol. 13, pp. 372-388, at p. 380).

Any lingering doubts were dispelled by the formal instruments of ratification, said Madison. "The explanatory declarations and amendments accompanying the ratifications of the several states formed a striking evidence, wearing the same complexion. He referred those who might doubt on the subject, to the several acts of ratification." (Madison, Speech on the Bank Bill, Papers of James Madison, 1991, vol. 13, pp. 372-388, at p. 380). These acts included nearly 100 proposals for narrowing the scope of Federal power, limiting its powers by reserving rights, and declaring reserved powers (Lutz, 1992).

Madison then put Congress itself on record as being opposed to broad interpretation of the "necessary and proper" clause. He reminded Representatives of their actions in 1789 in submitting a bill of rights to the states for their approval.

The explanatory amendments proposed by Congress themselves, at least, would be good authority with them; all these renunciations of power proceeded on a rule of construction, excluding the latitude now contended for. These explanations were the more to be respected, as they had not only been proposed by Congress, but ratified by nearly three-fourths of the states. He read several of the articles proposed, remarking particularly on the $11^{\text {th }}$ and $12^{\text {th }}$, the former, as guarding against a latitude of interpretation - the latter, as excluding every source of power not within the constitution itself. (Madison, Speech on the Bank Bill, Papers of James Madison, 1991, vol. 13, pp. 372-388, at pp. 380-381) ${ }^{2}$

With this canvass of "contemporary and concurrent" expositions of the understanding of "the parties to the instrument," Madison rested his case:

The $11^{\text {th }}$ and $12^{\text {th }}$ articles submitted to the states became the Ninth and Tenth Amendments, reserving unenumerated rights to the people, and undeclared powers to the states or the people, respectively. At the time of his speech, ratification of the bill of rights was nearly complete, though the amendments had not yet been approved by three-quarters of the states. 
With all this evidence of the sense in which the constitution was understood and adopted, will it not be said, if the bill should pass, that its adoption was brought about by one set of arguments, and that it is now administered under the influence of another set; and this reproach will have the keener sting, because it is applicable to so many individuals concerned in both the adoption and administration. (Madison, Speech on the Bank Bill, Papers of James Madison, 1991, vol. 13, pp. 372-388, at p. 381)

The contrast with Hamilton could not be sharper. As Madison put it later in life,

whatever respect may be thought due to the intention of the Convention which prepared and proposed the Constitution, as presumptive evidence of the general understanding at the time of the language used, it must be kept in mind that the only authoritative intentions were those of the people of the states, as expressed through the Conventions which ratified the Constitution. (Madison, May 1830 Letter from James Madison to M.L. Hurlbert, Writings of James Madison, 1910, vol. 9, pp. 370375, at p. 372)

\section{Original Understanding of Parties to the Instrument}

It was the intent of the people in each state, or a majority of their agents in the ratifying conventions, that guided Madison's interpretation of the Constitution. Important changes in the framework of government and allocation of powers must derive from the same source, in his view; they cannot be made by political authorities whose oaths commit them to upholding the Constitution. Changes must be the result of amendments to the Constitution ratified by the states, either in conventions or by their legislatures. In the course of ratifying amendments these "parties to the instrument" establish a new understanding of government's powers, responsibilities and limits, which then becomes the point of reference in Constitutional interpretation.

I consider amendments to the original understanding in a later section of this essay. Here I want to outline Madison's conception of ratification and analyze the process of ratification he successfully championed in Philadelphia. That process was designed to limit specific "mischiefs of faction" associated with democratic politics, while respecting the people's right to decide how they will be governed, and ultimately by whom. There is some tension between these objectives, and it is interesting to see how Madison balanced his fear of majority tyranny with his fundamental commitment to popular sovereignty.

Delegates to the Philadelphia convention were charged with recommending amendments to the Articles of Confederation, which stipulated that no changes could be made without the unanimous consent of states in the confederation. 
The requirement of unanimity defeated earlier attempts to alter the Articles, and it was widely assumed that Rhode Island opposed the plan for union. Approval might also be difficult to obtain in other states, so the convention proposed in Article VII that the Constitution would go into effect when it was approved by at least nine states (though its operation would be confined to the approving states). The Confederal Congress did not object, owing to the absence of key delegates, and forwarded the entire proposal, including Article VII, to the sovereign states for their consideration. All thirteen states complied with the request to hold ratifying conventions, in effect amending the Articles of Confederation's amendment procedure.

The proposed Constitution further stipulated that special conventions would decide the question of ratification in each state. This allowed Federalists to bypass state legislatures, where Antifederalists were well-represented and mobilized against the Constitution. As members of the dominant institutions of the day, legislators of all persuasion had a vested interest in guarding state sovereignty, increasing the likelihood of a hostile reception for the proposed Constitution. Thus, construction of the ratification process by the Philadelphia convention was deeply political, thoroughly partisan, and highly effective in tilting the ground in favor of ratification. Of course, it was defended in more palatable, but not inconsistent, terms.

From Madison's point of view the proposed method of ratification offered the best chance of obtaining a reasonable hearing on the plan and its merits. It was certainly better than seeking approval directly from the people, whose sovereignty was acknowledged by all, but whose political competence was doubted by most political elites. Ratification by state legislatures was similarly flawed. Madison blamed state legislatures for many of the "vices" of Confederation (Madison, Vices of the Political System of the United States, Papers of James Madison, 1991, vol. 9, pp. 346-357). Representatives were all too willing to sacrifice the interests of their constituents and the public good in pursuit of their own interests and ambitions. The few "honest but unenlightened" men who kept the public good in view were frequently dupes "of a favorite leader" who veiled "his selfish views under the professions of public good, and varnishing his sophistical arguments with the glowing colours of popular eloquence." (Madison, Vice of the Political System of the United States, Papers of James Madison, 1991, vol. 9, item 11).

Conventions solved the problem, or at least increased the likelihood that reason would triumph. They allowed for a "filtration of talent" in constitutional decision making like that which Madison praised in Federalist 10, wherein he touted the advantages of electing representatives from populous constituencies. Public opinion would be refined in the process of selecting delegates who commanded the respect of different interests in the community, men who were disposed to deliberate on the public good. For as Madison confided to Edmund Randolph, 
there can be no doubt that there are subjects to which the capacities of the bulk of mankind are unequal, and on which they must and will be governed by those with whom they happen to have acquaintance and confidence. The proposed Constitution is this description. The great body of those who are both for \& against it, must follow the judgment of others not their own. (Madison, Letter from James Madison to Edmund Randolph, Papers of James Madison,1991, vol. 10, pp. 354-356, at p. 355)

Madison probably overestimated the deliberative potential of ratifying conventions, and his own remarks to the Virginia convention kept reminding others to lay aside their "feelings and passion" in order to "decide this great question by a calm and rational investigation." (Madison, Speech to the Virginia Ratifying Convention, Elliot 1881, vol. 3, at pp. 66-67). But his confidence in the process was not misplaced. During the course of debating the Constitution and its meaning, conventions in several states, including New York and Virginia, reached a political accommodation on what to do about a bill of rights. ${ }^{3}$ Enough Antifederalists dropped their demand for "conditional ratification," settling for the alternative of proposing amendments to Congress for immediate consideration after the Constitution was approved. Federalists agreed, once it was evident that the Constitution's fate was at stake. ${ }^{4}$

The need for compromise was acute in Virginia, where the convention was almost evenly split. Madison led the fight against conditional ratification, and the Constitution was finally approved by 89 delegates, with 79 delegates voting against it. However, the instrument of ratification was sent to Congress with a long list of proposed amendments, which was approved by 85 votes, with 65 delegates voting no. The list included 20 proposals for declaring rights and liberties, one of which stated, "That all power is naturally vested in and consequently derived from the people; that Magistrates, therefore, are their trustees and agents and at all times amenable to them." Another 20 changes to the interior of the Constitution were recommended, too, among them a declaration "That each State in the Union shall respectively retain every power, jurisdiction and right which is not by this Constitution delegated to the Congress of the United States or to the departments of the Foderal Government." (Resolution of the Virginia Ratifying Convention, Elliot, 1881, vol. 3, at p. 661). The proposed amendments collectively expressed unease over the extent of powers conferred on Congress by the Constitution, and a desire to limit those powers in explicit terms.

Furthermore, the resolution listing the proposed amendments concluded with the injunction that Virginia's representatives in the new Congress "exert all

3 Gillespie and Lienesch (1989) analyze ratification controversies over important issues in each state.

4 "Conditional ratification" meant approving the Constitution on the condition that it was subsequently modified in accordance with proposals forwarded by a ratifying convention. The implication was that a state's approval was withdrawn if the Constitution was not amended to its liking. 
their influence, and use all reasonable and legal methods, to obtain a ratification of the foregoing alterations and provisions, in the manner provided by the $5^{\text {th }}$ article of the said Constitution; and, in all congressional laws to be passed in the mean time, to conform to the spirit of these amendments, as far as the said Constitution will admit." (ed. Elliot, 1881, p. 661).

This was not advisory; it was done "in the name and behalf of the people of this commonwealth." Hence Madison, who voted against the proposals in convention, felt obliged to respect this injunction upon his election to the first Congress.

The political compromise on the bill of rights was as much a part of the understanding of "parties to the instrument" as their unconditional ratification of the Constitution itself. Madison made this plain in a speech before the House of Representatives on June 8, 1789, wherein he urged Federalists to honor their promise to consider amendments to the Constitution and submit "to the state legislatures some things to be incorporated into the constitution, as will render it acceptable to the whole people of the United States, as it has been found acceptable to a majority of them.

Madison explained why this was essential:

notwithstanding the ratification of this system of government by eleven of the thirteen United States, in some cases unanimously, in others by large majorities; yet still there is a great number of our constituents who are dissatisfied with it; among them are many respectable for their talents, their patriotism, and respectable for the jealousy they have for their liberty, which, though mistaken in its object, its laudable in its motive. There is a great body of the people falling under this description, who at present feel much inclined to join their support to the cause of federalism, if they were satisfied on this one point: We ought not to disregard their inclination, but, on principles of amity and moderation, conform to their wishes, and expressly declare the great rights of mankind secured under this constitution. (Madison, June 8, 1789 Speech to the House of Representatives, 1991, Papers of James Madison, vol. 12, pp. 196-210, at p. 198)

Madison still believed that checks and balances, not the "parchment barriers" presented by a bill of rights, were the best means of securing liberty, but he also knew that Federalists could increase support for the constitutional machinery by satisfying the clamor for a bill of rights. This would undercut critics of the new regime and improve the chances for obtaining ratification in North Carolina and Rhode Island, where the absence of a bill of rights was a rallying point for Antifederalists. In that sense, a bill of rights would complete the union geographically, and bring the Constitution into alignment with the will of the people, as expressed in the ratifying conventions.

Madison's primary concern in his speech on the bill of rights was honoring the understanding that was achieved in 1787-1788, for that understanding was the source of legitimacy for checks and balances. The same concern pervad- 
ed his speeches on the bank bill, with their emphasis on "contemporary and concurrent expositions" of the Constitution's meaning. Madison extended this line of argument in 1791, however. Congress should defer to the original understanding out of respect for the people who ordained and established the Constitution, and if any Federalists were undecided on this point, they ought to consult their current constituents on the matter. Indeed, they also should consider the rights of future generations, "who have equal rights with ourselves, and with the aid of experience will be more capable of deciding on the subject, an opportunity of exercising that right, for an immoderate term." (James Madison, Speech on the Bank Bill, Papers of James Madison, vol. 10, pp. 372-382, at p. 379).

\section{Maintaining the Regnant Understanding}

The Constitution outlined a framework of government, but left many important questions to be resolved, e.g. the organization of the Federal judiciary and structure of executive agencies. Was there any assurance that the meaning of the Constitution, as it was understood by the "parties to the instrument," would be respected during this critical period of implementation? What prevented a faction from claiming powers not countenanced in the understanding of "parties to the instrument," but for which there might be some constitutional pretext, however slight?

Madison's answer to this question changed over the course of his political career. Initially, he placed great confidence in the machinery of checks and balances, which, he thought, would prevent usurpations of power - or at least minimize their likelihood and provide mechanisms for correcting any that occurred. Thus, in Federalist 51 he praised the Philadelphia convention for "so contriving the interior structure of the government, as that its several constituent parts may, by their mutual relations, be the means of keeping each other in their proper places." (Madison, Federalist 51, 2003, pp. 251-255, at p. 251). The separation of powers enabled each "constituent part" to defend against the encroachment of others, most especially the legislature, which in a republic was the dominant branch of government.

Moreover, each constituent part had a will of its own, based on its mode of selection. The House was directly elected, Senators were selected by state legislatures, the President was chosen by the Electoral College, and members of the Supreme Court were appointed by the President with the advice and consent of the Senate. Each mode of selection defined an institution's relation to the public, and hence its "collection" or sense of public opinion. The variety of modes allowed different conceptions of the public good to enter the political process, providing outlets for the diversity of interests in an extended republic. The re- 
sulting political machinery was largely self-regulating, or so Madison thought at the time (Kammen, 1986). ${ }^{5}$

Madison's belief in the efficacy of a "compound government" for an "extended republic" led him to play down an obvious solution to the problem of enforcing the ratified understanding of the Constitution and its meaning. His ally, Thomas Jefferson, suggested "that whenever any two of the three branches of government shall concur in opinion, each by the voices of two thirds of their whole number, that a convention is necessary for altering the constitution or correcting breaches of it, a convention shall be called for the purpose." ${ }^{\prime \prime}$ This proposal, Madison noted, was based on the idea that "As the people are the only legitimate fountain of power, and it is from them that the constitutional charter, under which the several branches of government hold their power, is derived; it seems strictly consonant to the republican theory, to recur to the same original authority, not only whenever it may be necessary to enlarge, diminish, or newmodel the powers of the government; but also whenever any one of the departments may commit encroachments on the chartered authorities of the others." (Madison, Federalist 49, 2003, pp. 245-248, at p. 245).

Acknowledging the force of this argument, Madison agreed that "a constitutional road to the decision of the people ought to be marked out and kept open, for certain great and extraordinary occasions," i.e. "whenever it may be necessary to enlarge, diminish, or new-model the powers of the government." He nevertheless opposed a periodic "recurrence to the people, as a provision in all cases for keeping the several departments of power within their constitutional limits." "In the first place," Madison wrote, "the provision does not reach the case of a combination of two of the departments against the third." In the next place, "it may be considered as an objection inherent in the principle, that as every appeal to the people would carry an implication of some defect in the government, frequent appeals would, in a great measure, deprive the government of that veneration which time bestows on every thing, and without which perhaps the wisest and freest governments would not possess the requisite stability." (Madison, Federalist 49,2003 , pp. $245-248$, at p. 246 ).

One casualty of this might be the system of checks and balances itself, which might be discarded in a fit of passion by a majority impatient with obstacles placed in its way by the Constitution.

But the greatest objection, according to Madison, was that members of Congress would sit in judgment of challenges to their authority.

Recent, and relevant, scholarship includes Rakove, 1996; Bailey, 2015; and especially Shankman, 2018.

6 Madison quotes the constitutional proposal Jefferson appended to his Notes on the State of Virginia. 
The same influence which had gained them an election into the legislature, would gain them a seat in the convention. If this should not be the case with all, it would probably be the case with many, and certainly with those leading characters, on whom every thing depends in such bodies. The convention, in short, would be composed chiefly of men who had been, who were, or who expected to be, members of the department whose conduct was arraigned. They would consequently be parties to the very question to be decided by them. (Madison, Federalist 49, 2003, pp. 245-248, at pp. 247-248)

An effective challenge to the legislature could arise only if one of its factions sided with the other branches, or the executive was "a peculiar favorite of the people." Even then, the issue

could never be expected to turn on the true merits of the question. It would inevitably be connected with the spirit of pre-existing parties, or of parties springing out of the question itself. It would be connected with persons of distinguished character and extensive influence in the community. It would be pronounced by the very men who had been agents in, or opponents of, the measures to which the decision would relate. The passions therefore not the reason, of the public, would sit in judgment. But it is the reason of the public alone that ought to control and regulate the government. The passions ought to be controulled and regulated by the government. (Madison, Federalist 49, pp. 245-248, at pp. 247-248)

All things considered, Madison thought it very unwise to charge the people with enforcing their understanding of the Constitution on political leaders. Instead he relied on checks and balances to keep government within bounds, and if that proved ineffective, the solution was to amend the Constitution, not merely to remedy abuses of power, but to prevent their recurrence in the future. This resolution of the problem of Constitutional enforcement seemed adequate in 1789 , but Madison was soon compelled to recommend an intermediate role for the people in matters of constitutional interpretation, a role that went beyond normal politics, but fell short of amending the Constitution.

\section{Amended Understandings}

Madison concurred with Jefferson that "a constitutional road to the decision of the people ought to be marked out and kept open, for certain great and extraordinary occasions," i.e. "whenever it may be necessary to enlarge, diminish, or new-model the powers of the government." Toward that end he proposed an intricate method for amending the Constitution (Kyvig, 1996). Article V specified that extraordinary majorities in Congress could propose amendments for states to consider, or that an extraordinary majority of states could forward proposals to Congress for deliberation. 
Several features of the amendment process deserve emphasis. First, it is extremely arduous; indeed Patrick Henry told the Virginia ratifying convention that "the way to amendment is, in my conception, shut." (Henry, June 16, 1788 Speech in the Virginia Ratifying Convention, in Elliot, 1881, vol. 3, p. 49). Madison disputed that claim, noting it was easier to obtain an extraordinary majority of three-fourths of all states than it was to gain their unanimous consent, as the Articles of Confederation required. In the short run he was vindicated, for a block of ten amendments was ratified by the end of 1791, barely two years after it was submitted to the states for consideration. ${ }^{7}$ The Eleventh Amendment was proposed in 1794 and approved 11 months later, and the Twelfth Amendment was added 6 months after it was passed by Congress in December, 1803.

Precisely because amendments replace one understanding of the Constitution with another, they must enjoy the consent of the people. Hence Madison and the delegates in Philadelphia required amendments to receive approval by three-fourths of the states in the union. While this fell short of unanimous consent, it is an extraordinary majority in several senses of that term. It is extraordinarily large in number, larger in fact than was needed for the union to come into existence in the first place: 10 of 13 states would have had to approve the Constitution under this rule. Amendments are usually approved by a geographically broad coalition of states, and while it is possible that a regional minority of states might be overcome, that is quite unlikely under the $75 \%$ threshold for approval. Finally, the winning coalition must be extraordinarily durable in order to survive the rigorous process and make the change permanent.

These qualities suggest that an extraordinary majority in a diverse or extended polity will not be tyrannical, according to Madison's definition in Federalist 10:

By faction I understand a number of citizens, whether amounting to a majority or minority of the whole, who are united and actuated by some common impulse of passion, or of interest, adverse to the rights of other citizens, or to the permanent and aggregate interests of the community. (Madison, Federalist 10, 2003, pp. 40-46, at p. 41).

Simple majorities of the moment are the faction to be feared most in a republic, but extraordinary majorities are not much of a danger because they must accommodate others in order to obtain the requisite size. Thus, the amendment procedure blocks momentary majority factions, without preventing an extraordinary majority from determining its political arrangements.

Twelve amendments were submitted to the states on September 25, 1789. Two failed to win approval at the time, one to enlarge the House of Representatives, the other to limit Congress's power to set its own compensation. The compensation amendment was eventually ratified in 1992; the submission to the states failed to specify a deadline for approval, as is now customary. 
At Madison's instigation, delegates in Philadelphia left the mode of amendment to the discretion of Congress, after much debate. Madison probably assumed that Congress would generally bypass state legislatures in favor of conventions. As we have seen, this placed the resolution of "great and extraordinary" questions in the hands of men who, in Madison's judgment, were responsible decision makers. Reason would prevail in ratifying conventions, whereas passions ruled most legislatures. Indeed, Madison might have preferred to eliminate the option of submitting proposed amendments to state legislatures, but political realities required an acknowledgement of those bodies who would decide how the ratification of the Constitution itself was going to proceed.

Every detail in the design of the amendment process underscores Madison's desire to make changes in the Constitution a matter of mutual accommodation. In order to obtain the requisite majority, proponents of change cannot frame their amendments in terms of narrow interests. They must identify the change with general concerns, and in the course of explaining and justifying the amendment they must show how the amendment serves the public good or the interest of all. Otherwise the amendment can be defeated by a minority, or a coalition of minorities, who believe their interests are better served by the status quo.

Debates on amendments either re-ratify an existing agreement, or usher in new understandings of how the Constitution is modified by changes in language. The new understanding then becomes the touchstone for Constitutional interpretation. Thus, Madison's deference to the meaning attached to the Constitution by the "parties to the instrument" may be termed "originalism" only if we remember that the origin in question is not a moment in time, but the source of meaning or power. The people are sovereign in a republic, and only they can modify government or place it on a new footing or understanding. In that sense popular sovereignty is inherently open-ended; it cannot be frozen in time.

The "meaning of the parties to the instrument" is dynamic in another sense, too. The parties to an amended Constitution are not necessarily those who established the Constitution in the first place. Newly admitted states became parties to the instrument, enjoying a status equal to the original parties. A small number of new states could prevent the original parties from amending the Constitution, even if the latter were numerous. For that matter, it is possible that enough new states could amend the constitution over the objection of most or even all the original parties, although this, too, is unlikely. Hence the "meaning of parties to the instrument" moves forward in time with each new expression of the will of the people, or each expression of the will of a newly defined people.

Madison embraced the right of the people to alter or abolish their government, but he was aware that power might be misdirected by demagogues or hijacked by factions. That awareness was displayed in the fight for a bill rights in the House of Representatives, where he made sure that the block of amendments submitted to the states did not undermine the system of checks and bal- 
ances, he cherished. That was a possibility, since Antifederalists in the ratifying conventions included numerous suggestions for structural changes in the Federal government, as well as numerous limitations on its powers, with proposals to declare fundamental rights and liberties beyond reach of Congress, the President, and the courts. Indeed, the entire collection of proposed amendments, if accepted by "parties to the instrument," would have reduced the Constitution to a modestly improved version of the Articles of Confederation, if that.

Madison's own actions in 1789 exhibited the balancing of interests he associated with fair and just government. He did not see himself as thwarting the will of people in blocking structural changes to the system of checks and balances. To the contrary, he understood himself to be carrying out the will of the people, who had given their approval to the Constitution AND expressed their desire to see fundamental liberties formally declared in it. Evidently, the popular will was no more singular than the intentions of the Framers.

\section{Public Opinion}

Frustrated by his inability to restrain members of his own party on the bank bill in 1791, Madison defected to the opposition and became the chief polemicist for the Jeffersonian Republicans. He attacked the Federalists for subverting the Constitution and considered ways of containing them. Toward that end Madison sought to bring public opinion to bear on the Federalist government, hoping to limit its energy and check its power. Thus, in the National Gazette in January of 1792, Madison warned that "Liberty and order will never be perfectly safe, until a trespass on the constitutional provisions for either, shall be felt with the same keenness that resents an invasion of the dearest rights." (Madison, Charters, Papers of James Madison, 1991, vol. 14, pp. 191-192, at p. 192).

Returning to the point two weeks later, Madison used even stronger language to alert citizens to Federalist breaches of the public trust:

in bestowing eulogies due to the partitions and internal checks of power, it ought not the less to be remembered, that they are neither the sole nor the chief palladium of constitutional liberty. The people who are the authors of this blessing, must also be its guardians. Their eyes must be ever ready to mark, their voices to pronounce, and their arms to repel aggressions on the authority of their constitutions; the highest authority next to their own, because the immediate work of their own, and the most sacred part of their property, as recognizing and recording the title to the other. (Madison, Government of the United States, Papers of James Madison, 1991, vol. 14, pp. 271-219, at p. 218)

Madison was not only trying to sway public opinion against the Federalists in these articles. He was also trying to reactivate the established "meaning 
of parties to the instrument" or regnant understanding of limited government. For him the problem was simply that the people, who were already on record as strict constructionists, lacked information about government abuses of power. The extent of the republic made it difficult for citizens to monitor the Representatives and hold them accountable. Hence Madison endorsed "whatever facilitates a general intercourse of sentiments, as good roads, domestic commerce, a free press, and particularly a circulation of newspapers through the entire body of the people, and Representatives going from, and returning among every part of them, is equivalent to a contraction of territorial limits, and is favorable to liberty, where these may be too extensive." (Madison, Public Opinion, Papers of James Madison, 1991, p. 170 at p. 170).

His solution presumed that Federalists were out of touch with the silent majority, and that the electorate was unaware of their usurpations of power. Unfortunately for Madison, this presumption was incorrect. Not only did the Federalists retain control of the Presidency, they also dominated Congress, except for a brief time in the mid-1790s. Federalists deftly courted public opinion in the XYZ Affair and played on tense relations with France to pass the Alien and Sedition Acts in the summer of 1798 . These four acts undermined the Jeffersonian Republicans, muzzling their criticism of the Adams administration and limiting their ability to recruit supporters from the swelling immigrant population.

Stymied in their efforts to actuate public opinion and bring it to bear on lawmakers through the electoral process, Jeffersonian Republicans turned to a more sympathetic site of opposition to Federalist policy: state legislatures. If public opinion could not be mobilized directly, perhaps public opinion leaders in the states could be organized against Federalists in Congress. With that in mind, Jefferson conceived the Kentucky Resolutions, and persuaded Madison to draft the Virginia Resolutions condemning the Alien and Sedition Acts. The situation was so desperate that Madison, whose antipathy toward state legislatures ran deep, was nevertheless induced to stand for election to the Virginia Assembly in 1799. As a member of the state legislature he wrote the "Report of 1800 " elaborating the constitutional arguments put forward in the Virginia Resolutions.

The resolutions identified a new avenue for expressing public opposition to Federal power. The Virginia Resolution stated that

this Assembly doth explicitly and peremptorily declare, that it views the powers of the federal government, as resulting from the compact to which the states are parties; as limited by the plain sense and intention of the instrument constituting that compact; as no farther valid than they are authorized by the grants enumerated in that compact, and that in case of a deliberate, palpable and dangerous exercise of other powers, not granted by the said compact, the states who are parties thereto have the right, and are in duty bound, to interpose for arresting the progress of evil, and for maintaining within their respective limits, the authorities, rights and 
liberties appertaining to them. (Madison, Report of 1800, Papers of James Madison, 1991, pp. 303-351, at p. 308)

The Resolutions insisted on the "plain sense and intention of the instrument" of union, but they did not specify the meaning of interposition, nor did they justify actions that other state legislatures interpreted as a threat to the federal republic. Madison clarified matters in the Report of 1800, wherein he characterized the declarations as an appeal "emphatically made to the intermediate existence of the state governments, between the people and that government, to the vigilance with which they would descry the first symptoms of usurpation, and to the promptitude with which they would sound the alarm." (Madison, Report of 1800, Papers of James Madison, 1991, pp. 303-351, at p. 350). As such the resolutions were "expressions of opinion, unaccompanied with any other effect, than what they may produce on opinion, by exciting reflection." (Madison, Report of 1800, Papers of James Madison, 1991, pp. 303-351, at p. 348).

True,

other means might have been employed, which are strictly within the limits of the constitution. The legislatures of the states might have made a direct representation to Congress, with a view to obtain a rescinding of the two offensive acts; or they might have represented to their respective senators in Congress, their wish, that two thirds thereof would propose an explanatory amendment to the constitution; or two thirds of themselves, if such had been their option, might, by an application to Congress, have obtained a convention for the same object. (Madison, Report of 1800, Papers of James Madison, 1991, pp. 303-351, at p. 349) ${ }^{8}$

But these remedies could not proceed without prior efforts to mobilize the states against the offending acts. The Virginia and Kentucky Resolutions were therefore "the first and most obvious proceeding on the subject." (Madison, Report of 1800, Papers of James Madison, 1991, pp. 303-351, at p. 349).

Thus, Madison had discovered an intermediate mechanism for checking the expansion of Federal power, one that placed state governments between national authorities and the people. Interposition, or the mobilization of state governments, stopped short of amendment, but the implied threat of amendment lent force to the act. The amount of force depended on the extent to which states acted in concert as "parties to the instrument." Much to his chagrin, Madison discovered that most other states refused to join the symphony being orchestrated by him and Jefferson. Indeed, the Report of 1800 was written in response to res-

Madison distinguished interposition, a form of collective action, from the unilateral "nullification" suggested by Jefferson, which Madison rejected as being inconsistent with a compact theory of ratification. 
olutions from other states whose Federalist legislatures accused the Virginia Assembly of undermining the Union. ${ }^{9}$

Ultimately, Jefferson and the Republican opposition were saved by the political process in which Madison originally invested his confidence. The election of 1800 led to a massive, but peaceful, transfer of power to the Jeffersonian Republicans. The Federalists never regained power at the national level, though they did exact revenge on Madison during the unpopular War of 1812. "Mr. Madison's War," as they dubbed it, was underwritten by the national bank created by Hamilton, and later re-authorized with Jefferson's approval.

As President, Madison was forced to accept the Bank, albeit grudgingly. As he explained to General Lafayette,

My construction of the Constitution on this point is not changed; but I regarded the reiterated sanctions given to the power by the exercise of it through a long period of time, in every variety of form, and in some form or other under every administration preceding mine, with the general concurrence of the State authorities, and acquiescence of the people at large, and without a glimpse of change in the public opinion, but evidently a growing confirmation of it; all this I regarded as a construction put on the Constitution by the nation, which having made it, had the supreme right to declare its meaning; and regarding, moreover, the establishment of a Bank, under the existing circumstances, as the only expedient for substituting a sound currency in place of the vitiated one then working so much mischief, I did not feel myself, as a public man, at liberty to sacrifice all these public considerations to my private opinion. (November 1826 letter from Madison to General Lafayette. James Madison Papers, 1823-1836, in The Founding Era Collection, University of Virginia Press ${ }^{10}$ )

Thus, Madison came to grudgingly endorse an informal mode of altering the Constitution. "The early, deliberate, \& continued practice under the Constitution, as preferable to constructions adapted on the spur of the occasions, and subject to the vicissitudes of party or personal ascendancies" is among the "obvious and just guides" for interpreting the Constitution." (Madison Letter to M.L. Hurlbert, Writings of James Madison, vol. 9, pp. 370-375, at p. 372). The people, it seems, express their will in ways unanticipated by theoreticians.

9 In his Report, Madison noted that the Philadelphia convention itself was called into existence by means of a similar communication among the states. As such, it was hard to see how the Virginia resolutions were in any sense "unconstitutional," as some states claimed.

10 https://rotunda.upress.virginia.edu/founders/default.xqy?keys=FOEA-print-02-02-02-0778. 


\section{References}

Bailey, J.D. (2015). James Madison and Constitutional Imperfection. Cambridge: Cambridge University Press.

Elliot, J. (ed.). (1881). "Resolution of the Virginia Ratifying Convention". In: The debates in the several state conventions on the adoption of the federal Constitution, as recommended by the general convention at Philadelphia, in 1787 Together with the Journal of the federal convention, Luther Martin's letter, Yates's minutes, Congressional opinions, Virginia and Kentucky resolutions of '98-'99, and other illustrations of the Constitution. [Online]. Philadelphia: J.B. Lippincott, p. 661. Available from: http:// books.google.com/books?id=2n40AQAAMAAJ [accessed: 8 December 2019].

Gillespie, M.A., Lienesch, M. (eds.). (1989). Ratifying the Constitution. Lawrence: University Press of Kansas.

Hamilton, A. (2003). "Federalist 23". In: T. Ball (ed.). The Federalist: with the 'Letters of "Brutus". Cambridge: Cambridge University Press, pp. 106-110.

Hamilton, A. (2003). “Federalist 30”. In: T. Ball (ed.). The Federalist: with the 'Letters of "Brutus". Cambridge: Cambridge University Press.

Hamilton, A. (2003). “Federalist 84”. In: T. Ball (ed.). The Federalist. Cambridge: Cambridge University Press, pp. 416-426.

Hamilton, A. (1972). The Papers of Alexander Hamilton. Eds. H.C. Syrett, J.E. Cooke. New York-London: Columbia University Press.

Kammen, M. (1986). A Machine That Would Go of Itself: The Constitution in American Culture. New York: Alfred A. Knopf.

Kyvig, D.E. (1996). Explicit and Authentic Acts: Amending the US Constitution, 17761995. Lawrence: University Press of Kansas.

Lutz, D.S. (1992). “The State Constitutional Pedigree of the U.S. Bill of Rights”. Publius, 22(2), pp. 19-45.

Madison, J. (2003). “'Charters', for the National Gazette, January 18, 1792”. In: The Papers of James Madison. Chicago: University of Chicago Press, pp. 191-192.

Madison, J. (2003). "February 2, 1791 Speech on the Bank Bill". In: The Papers of James Madison. Chicago: University of Chicago Press, pp. 372-382.

Madison, J. (2003). "February 8, 1791 Speech on the Bank Bill”. In: The Papers of James Madison. Chicago: University of Chicago Press, pp. 383-388.

Madison, J. (2003). "Federalist 10”. In: T. Ball (ed.). The Federalist: with the 'Letters of "Brutus". Cambridge: Cambridge University Press, pp. 40-46.

Madison, J. (2003). “Federalist 49”. In: T. Ball (ed.). The Federalist: with the 'Letters of "Brutus"'. Cambridge: Cambridge University Press, pp. 245-248.

Madison, J. (2003). "Federalist 51". In: T. Ball (ed.). The Federalist: with the 'Letters of "Brutus"'. Cambridge: Cambridge University Press, pp. 251-255.

Madison, J. (1991d). “'Government of the United States,' for the National Gazette, February 4, 1792”. In: The Papers of James Madison. Chicago: University of Chicago Press, pp. 217-219.

Madison, J. (1991e). “January 10, 1788 Letter from James Madison to Edmund Randolph". In: The Papers of James Madison. Chicago: University of Chicago Press, pp. 354356. 
Madison, J. (1991f). “June 8, 1789 Speech to the House of Representatives”. In: The Papers of James Madison. Chicago: University of Chicago Press, pp. 196-210.

Madison, J. (1881). "June 16, 1788 Speech to the Virginia Ratifying Convention". In: J. Elliot (ed.). The debates in the several state conventions on the adoption of the federal Constitution, as recommended by the general convention at Philadelphia, in 1787 Together with the Journal of the federal convention, Luther Martin's letter, Yates's minutes, Congressional opinions, Virginia and Kentucky resolutions of '98-'99, and other illustrations of the Constitution. [Online]. Philadelphia: J.B. Lippincott, pp. 66-67. Available from: http://books.google.com/books?id=2n40AQAAMAAJ. [Accessed: 8 December 2019].

Madison, J. (2008). “May 1830 Letter from James Madison to M.L. Hurlbert”. In: G. Hunt (ed.). The Writings of James Madison. New York: G.P. Putnam's Sons, pp. 370-375. [Online]. Available from: http://oll.libertyfund.org/title/1933. [Accessed: 7 December 2019].

Madison, J. (1991g). “Public Opinion,' for the National Gazette, December 19, 1791”. In: The Papers of James Madison. Chicago: University of Chicago Press, p. 170.

Madison, J. (1991h). "Vices of the Political System of the United States, April 1787". In: The Papers of James Madison. Chicago: University of Chicago Press, pp. 346-357.

Madison, J. (1991i). "Virginia Resolutions, December 21, 1798”. In: The Papers of James Madison. Chicago: University of Chicago Press, p. 308.

Rakove, J.N. (1996). Original Meanings: Politics and Ideas in the Making of the Constitution. New York: Alfred A. Knopf.

Shankman, A. (2018). Original Intents: Hamilton, Jefferson, Madison, and the American Founding. Oxford: Oxford University Press.

Storing, H.J. (1981). What the Anti-Federalists Were For. Chicago: University of Chicago Press. 